\title{
ANÁLISE DA SEGREGAÇÃO SOCIOESPACIAL EM UBERLÂNDIA-MG A PARTIR DE CONJUNTOS HABITACIONAIS (2009-2016) ${ }^{1}$
}

\author{
Rodrigo de Araújo² \\ Lussandra Martins Gianasi ${ }^{3}$
}

Resumo: Este artigo analisou o processo de segregação socioespacial a partir de conjuntos habitacionais, em Uberlândia (Minas Gerais) de 2009 a 2016. Como procedimentos metodológicos, foram utilizados os levantamentos bibliográfico, documental e cartográfico, sendo possível, portanto, evidenciar a localização periférica de tais conjuntos habitacionais em contraste com grandes vazios urbanos. Além disso, investigou-se a regulamentação e a aplicação das leis de Parcelamento, Edificação ou da Utilização Compulsórios (PEUC) e o Imposto Predial e Territorial Urbano (IPTU) progressivo no tempo, que ocorreram de forma lenta e controversa no município de Uberlândia-MG, resultando na manutenção da especulação imobiliária. Ademais, foi possível compreender de que forma o mercado imobiliário e as construtoras participam e se apropriam dos programas habitacionais, bem como eles atuam junto ao poder público local no que concerne à localização de tais conjuntos habitacionais, evidenciando a prevalência dos interesses de mercado sobre a função social da propriedade urbana.

Palavras-chave: Segregação socioespacial; Conjuntos habitacionais; Programa Minha Casa, Minha Vida; Expansão urbana; Estatuto da cidade.

\section{ANALYSIS OF SOCIO-SPATIAL SEGREGATION IN UBERLÂNDIA-MG FROM HOUSING ESTATES (2009- 2016)}

\begin{abstract}
This article analysed the process of socio-spatial segregation from the social housing estates in Uberlândia-MG from 2009 to 2016. As methodological procedures, bibliographic, documentary, and cartographic surveys were used, making it possible, therefore, to evidence the peripheral location of such social housing estates in contrast to large urban voids. In addition, it studied the regulation and application of law of subdivision, building or use compulsory and of time-progressive urban land tax, which occurred slowly and controversially in the municipality of Uberlândia-MG, resulting in the maintenance of real estate speculation. Moreover, it was possible to understand how the real estate market and construction companies participate and appropriate the social housing programs, as well as how they act together with the local government regarding the location of such housing developments, evidencing the prevalence of market interests over the social function of urban property.
\end{abstract}

\footnotetext{
${ }^{1}$ Este trabalho é parte integrante e revisada do Trabalho de Conclusão de Curso intitulado "EXPANSÃO URBANA DE UBERLÂNDIA-MG: um estudo sobre a segregação socioespacial a partir de conjuntos habitacionais (2009-2016)".

${ }^{2}$ Bacharel em Geografia pela Universidade Federal de Minas Gerais UFMG). E-mail: rodrigodearaujomg@ gmail.com.

${ }_{3}^{3}$ Doutora em Geografia. Professora do Departamento de Geografia do IGC/UFMG. E-mail: lussandrams@ gmail.com.
} 
Keywords: Socio-spatial segregation in Uberlândia-MG; Social housing estates; "Minha Casa, Minha Vida" program; Urban sprawl; City statute.

\section{INTRODUÇÃO}

Desde meados do século XX no Brasil verificou-se um amplo processo de urbanização proporcionado pelo êxodo populacional proveniente do meio rural que buscava, além de trabalho, melhores condições de vida (SANTOS, 1981). Segundo Matos e Baeninger (2004), além das migrações, outro fator que contribuiu para a urbanização foi o crescimento demográfico devido à redução da taxa de mortalidade. Nesse sentido, Santos (1993) complementa que outros fatores contribuintes para o crescimento demográfico foram: a diminuição da taxa de mortalidade; o aumento das taxas de natalidade; melhorias no padrão de vida e das condições sanitárias; bem como o próprio processo de urbanização.

Dessa forma, segundo dados do Instituto Brasileiro de Geografia e Estatística (IBGE), em 1940, a taxa de urbanização da população brasileira era representada por $31,24 \%$, ao passo que a partir da década de 1970, o Brasil passou a ser essencialmente urbano, sendo auferida uma taxa de 55,92\% (IBGE, 2020), enquanto no Censo de 2010, foi observada uma taxa de urbanização de 84,36\% (IBGE, 2020).

Conforme Maricato (2003), a partir da década de 1980, as periferias urbanas se estenderam criando extensas áreas de segregação socioespacial. Segundo a autora:

A segregação urbana ou ambiental é uma das faces mais importantes da desigualdade social e parte promotora da mesma. À dificuldade de acesso aos serviços e infraestrutura urbanos (transporte precário, saneamento deficiente, drenagem inexistente, dificuldade de abastecimento, difícil acesso aos serviços de saúde, educação e creches, maior exposição à ocorrência de enchentes e desmoronamentos etc.) somam-se menos oportunidades de emprego (particularmente do emprego formal), menos oportunidades de profissionalização, maior exposição à violência (marginal ou policial), discriminação racial, discriminação contra mulheres e crianças, difícil acesso à justiça oficial, difícil acesso ao lazer (MARICATO, 2003, p 152).

Sendo assim, entende-se que o processo de urbanização ocorrido no Brasil, sobretudo a partir da década de 1930, devido ao seu ritmo e sua proporção, combinados com um planejamento ineficiente e/ou a ausência de interesse político, constituiu-se como a gênese de uma série de problemas que fazem parte do cotidiano das cidades na atualidade, dentre eles, a segregação socioespacial. Pois, ao segregar o espaço geográfico, criam-se espaços luminosos e espaços opacos (SANTOS, 2006), materializando-se em um espaço fragmentado, onde determinados grupos sociais têm privilégios na sua ocupação espacial no espaço urbano, em detrimento de outros grupos, evidenciando, assim, a desigualdade socioespacial e econômica do nosso país.

Diante disso, a questão habitacional surge como um grande desafio, visto que o acesso desigual à terra ou à moradia, propriamente dita, é decorrente de uma ampla desigualdade socioeconômica. Nesse sentido, destaca-se o Programa Minha Casa, Minha Vida (PMCMV), que foi criado em 2009, possuindo como objetivo, ser um programa voltado, sobretudo, para a parte econômica, com o propósito de 
aquecimento da cadeia produtiva. Com isso, buscava-se a integração de toda a cadeia de produção imobiliária, desde a matéria-prima para a construção civil até a indústria moveleira e de eletrodomésticos. Sendo assim, em pouco mais de cinco anos de existência, entregou cerca de três milhões de unidades para famílias de 0 a 10 salários-mínimos (AMORE, 2015). Além disso, destaca-se a inclusão da participação de associações, cooperativas e entidades afins na concepção de conjuntos habitacionais voltados para famílias de baixa renda. Entretanto, embora o programa tenha passado por vários aprimoramentos e ampliações, vários problemas como, por exemplo, o déficit habitacional, ou ainda, marcas do $\mathrm{BNH}$, como a padronização das unidades habitacionais e a segregação socioespacial, ainda persistiram até sua descontinuidade, em 2020.

Nesse sentido, embora a segregação socioespacial urbana tenha surgido muito antes do capitalismo pós-industrial, ela se aprofunda na atualidade devido à atuação de determinados grupos sociais, perfazendo em uma problemática presente não apenas nas metrópoles, mas também, nas médias e grandes cidades, como é o caso de Uberlândia, no estado de Minas Gerais. Segundo Corrêa (2013), a segregação socioespacial se manifesta no espaço urbano de diversas formas, que podem ser a autossegregação, a segregação induzida ou a segregação imposta. A autossegregação corresponde ao isolamento deliberado dos médios e altos estratos sociais, se materializando no espaço urbano como condomínios fechados de alto padrão. Essa forma de segregação é aquela que o indivíduo possui a escolha do seu lugar de moradia de acordo com seus interesses e necessidades. Por outro lado, na segregação induzida ou imposta, o indivíduo é transferido, em muitos casos, sem a sua opção de escolha (CORRÊA, 2013).

Sendo assim, o planejamento da habitação de interesse social, uma vez elaborada e implementada por gestores do poder público, que, em muitos casos, são "empreendedores" do próprio mercado imobiliário ou da construção civil, respaldados por uma legislação criada por eles mesmos, possuem em suas mãos um grandioso instrumento de dominação capaz de induzir ou impor a segregação socioespacial de determinados grupos sociais, que neste caso, não definem seus próprios locais de moradia.

Com o propósito de incluir glebas à área urbana da cidade de Uberlândia, objetivando a implementação de loteamentos cujos projetos incluíram a concepção de conjuntos habitacionais, sendo eles, os residenciais, Fruta do Conde, Lago Azul, Monte Hebron e Pequis, houve em 2013, a alteração do perímetro urbano da cidade. Dessa maneira, conforme a Prefeitura Municipal de Uberlândia (PMU), a opção por ampliar o perímetro urbano, deu-se em virtude do alto valor da terra na área urbana, o que inviabilizaria a produção das unidades habitacionais. Porém, conforme Motta (2015), 40\% da área total do perímetro urbano de Uberlândia até o ano de 2015, era formado por vazios urbanos.

Diante disso, surge a discussão proposta sobre a função social da propriedade, presente no Estatuto da Cidade (Lei 10.257, de 10 de julho de 2001) que regulamenta o Art. 182 da Constituição Federal (CF), de 1988. Dessa forma, a referida lei assegura que o poder público local, pode instituir instrumentos compulsórios aos imóveis urbanos não utilizados/edificados ou subutilizados, que não cumprem a função social da propriedade urbana. Entretanto, para que isso se torne uma prática pelos municípios, foi necessária sua regulamentação a partir da própria legislação municipal, conforme os princípios do Estatuto da Cidade.

Assim sendo, é permitido inferir a seguinte questão: como os programas habitacionais de interesse social contribuem para a segregação socioespacial em 
Uberlândia-MG? Dessa forma, este artigo propõe discutir o fenômeno da segregação socioespacial na expansão urbana de Uberlândia - MG através de conjuntos habitacionais, abordando as segregações impostas ou induzidas pelo interesse das elites, sobretudo aquelas ligadas à produção imobiliária, que são asseguradas pelo poder público através da legislação municipal, bem como pela própria habitação social. Nesse sentido, foram estudados os principais conjuntos habitacionais de interesse social desenvolvidos na cidade de Uberlândia, construídos entre os anos de 2009 e 2016, desenvolvidos em âmbito federal (PMCMV), bem como os desenvolvidos nos âmbitos municipal e estadual (Tchau Aluguel e Lares Geraes). Este recorte temporal deve-se ao período de implementação dos conjuntos habitacionais do PMCMV, no município de Uberlândia, concomitantemente com os programas realizados em âmbito municipal e estadual.

Foram utilizados como procedimentos metodológicos os levantamentos bibliográfico, documental e cartográfico. Sendo assim, o levantamento bibliográfico consistiu em uma revisão teórica acerca da segregação socioespacial, enquanto o levantamento documental buscou enriquecer a pesquisa com informações sobre os programas habitacionais desenvolvidos na cidade de Uberlândia, bem como os conjuntos habitacionais implementados na cidade. Portanto, foram utilizadas como fontes de pesquisa, diários oficiais, leis, telejornais, matérias de jornais, bem como portais online de notícias, além de documentos oficiais da Prefeitura Municipal de Uberlândia (PMU). Por outro lado, o levantamento cartográfico, bem como sua produção, serviu como instrumento de elucidação das posições geográficas dos vazios urbanos na cidade de Uberlândia, inclusive em relação à localização dos conjuntos habitacionais na cidade. Além disso, foi possível realizar uma comparação acerca da localização dos conjuntos habitacionais, levando-se em conta, o programa, a faixa de renda dos contemplados e o porte do conjunto em relação ao número de unidades habitacionais.

\section{BREVE HISTÓRICO DO PROGRAMA MINHA CASA, MINHA VIDA}

O Programa Minha Casa, Minha Vida (PMCMV) surgiu em 2009 com o objetivo de enfrentar o déficit habitacional, bem como mitigar os efeitos da crise mundial surgida em 2007, nos Estados Unidos. Portanto, segundo Amore (2015), o programa surgiu como um plano econômico que buscava assegurar e melhorar os fluxos na economia, buscando incluir toda a cadeia de produção imobiliária, desde a extração de matéria-prima para a indústria da construção civil até o consumo de eletrodomésticos após a ocupação das unidades produzidas. Segundo o autor:

"[...] previa-se gerar empregos num setor da economia capaz de mobilizar diversos outros setores associados: desde a indústria extrativista e produtora dos materiais básicos da construção civil até a indústria moveleira e de eletrodomésticos, que é ativada no momento da entrega das chaves" (AMORE, 2015, p. 16-17).

Contudo, além de não assegurar um direito à moradia constante (AMORE, 2015), o programa provocou diversas críticas no que concerne às práticas de desenvolvimento, pois, conforme Souza (2017), a instituição de sistemas de financiamento, a articulação de agentes privados na concepção dos empreendimentos, bem como o direcionamento atribuído pela criação de legislações, acabaram por reproduzir as "[...] antigas práticas padronizadas de construção, desarticuladas no espaço urbano e arquitetonicamente questionáveis, 
desconsiderando as realidades municipais [...]" (SOUZA, 2017, p. 89). Portanto, reproduzindo velhas práticas desenvolvidas no âmbito do extinto Banco Nacional da Habitação (BNH).

Desde sua criação, o PMCMV foi implementado por fases, das quais sua dinâmica era aprimorada ou ampliada. Para a primeira fase (2009-2011), foi projetada a construção de um milhão de moradias, das quais $40 \%$ das moradias seriam destinadas às famílias com renda até três salários-mínimos (Faixa 1), 40\% às famílias com renda entre três e seis salários-mínimos (Faixa 2) e 20\% das unidades seriam destinadas às famílias da Faixa 3, ou seja, com renda entre seis e dez saláriosmínimos (SOUZA, 2017).

Segundo Amore (2015), para a segunda fase do PMCMV (2011-2014) foram propostas as construções de dois milhões de unidades, que seriam distribuídas seguindo a mesma lógica adotada para contemplação por faixas de renda. Conforme o autor, foram revistos os valores de renda para cada faixa (Figura 1), além do aumento do valor por unidade construída e a inclusão de especificações mínimas de construção, que incluíam, por exemplo, a exigência de acessibilidade à cadeirantes.

Figura 1. Faixas de renda do PMCMV, nas fases 1 e 2 (2009-2014).

\begin{tabular}{|c|c|c|}
\hline Fase & Faixa & Renda familiar mensal \\
\hline \multirow{3}{*}{ Fase 1} & Faixa 1 & Até $1.395,00$ reais \\
\hline & Faixa 2 & De $1.395,01$ a $2.790,00$ reais \\
\hline & Faixa 3 & De $2.790,01$ a $4.650,00$ reais \\
\hline \multirow{3}{*}{ Fase 2} & Faixa 1 & Até $1.600,00$ \\
\hline & Faixa 2 & De $1.600,01$ a $3.100,00$ reais \\
\hline & Faixa 3 & De $3.100,01$ a $5.000,00$ reais \\
\hline
\end{tabular}

Em relação às fontes de recursos do PMCMV, como no $\mathrm{BNH}$, também contava com aportes do FGTS e do Orçamento Geral da União (OGU), além de recursos das cadernetas de poupança. Amore (2015) explica que nas fases 1 e 2 do programa, foram utilizados recursos oriundos do Fundo de Arrendamento Residencial (FAR), que eram utilizados diretamente pelas prefeituras ou construtoras, bem como em parcerias entre estes agentes. Outro recurso era o Fundo de Desenvolvimento Social (FDS), voltado aos conjuntos habitacionais elaborados por associações, cooperativas e entidades sem fins lucrativos, através do Programa Minha Casa, Minha Vida Entidades (PMCMV-E). Já para as Faixas 2 e 3 eram utilizados recursos provenientes do FGTS.

No ano de 2016 foi lançada a terceira fase do PMCMV, que previa a construção de dois milhões de moradias com recursos do FGTS até o ano de 2018. De acordo com Bernardo (2018), "foi realizada uma série de alterações com relação ao Programa que vinha sendo executado, inclusive a criação de uma nova categoria, intermediária entre as faixas 1 e 2, a faixa 1,5" (BERNARDO, 2018, p. 169). Além disso, em 2016, - PMCMV passou por uma nova alteração nos limites de renda e de subsídio, bem como nos valores máximos das unidades habitacionais. Na tabela a seguir, é possível visualizar os referidos valores instituídos para a Fase 3 do PMCMV em 2016. 
Tabela 1. Valores de renda, subsídio, unidade habitacional e meta de unidades do PMCMV.

\begin{tabular}{|c|c|c|c|c|}
\hline Faixa & Renda familiar mensal & Subsídio & $\begin{array}{c}\text { Valor máximo por } \\
\text { unidade habitacional (R\$) }\end{array}$ & $\begin{array}{c}\text { Meta de unidades } \\
\text { habitacionais até } 2018\end{array}$ \\
\hline Faixa 1 & Até $\mathrm{R} \$ 1.800$ & Até $90 \%$ & $96.000,00$ & 500.000 \\
\hline Faixa 1,5 & De $R \$ 1.800$ até $R \$ 2.350$ & Até $R \$ 45.000$ & $135.000,00$ & 500.000 \\
\hline Faixa 2 & Até $\mathrm{R} \$ 3.600$ & Até $\mathrm{R} \$ 27.500$ & $225.000,00$ & 800.000 \\
\hline Faixa 3 & Até $\mathrm{R} \$ 6.500$ & - & $225.000,00$ & 200.000 \\
\hline
\end{tabular}

Fonte: Bernardo (2018). Organizado pelos autores, 2021

Sendo assim, embora o PMCMV não tenha sido oficialmente encerrado, conforme Brasil (2020), foi aprovada em dezembro de 2020 a Medida Provisória no $996^{4}$, de 25 de agosto de 2020, que institui o Programa Casa Verde e Amarela (PCVA). Portanto, espera-se que caso houvesse novas contratações, estas seriam vinculadas ao "novo" programa.

\section{A HABITAÇÃO DE INTERESSE SOCIAL EM UBERLÂNDIA-MG (2009- 2016): OBJETOS DA SEGREGAÇÃO SOCIOESPACIAL}

Desde o ano de 2009, ano de lançamento do PMCMV, até o ano de 2014, segundo dados da Caixa Econômica Federal (CEF, 2019), foram contratadas em Uberlândia-MG cerca de 11.548 unidades habitacionais voltadas para a Faixa 1 do programa (Tabela 2), das quais cerca de $80 \%$ foram entregues na tipologia de casas.

Tabela 2. Uberlândia (MG): Conjuntos habitacionais do PMCMV - Faixa $1(2009$ e 2014).

\begin{tabular}{|c|c|c|c|c|}
\hline CONJUNTO HABITACIONAL & $\begin{array}{l}\text { NÚMERO DE } \\
\text { UNIDADES }\end{array}$ & VALOR $(R \$)$ & $\begin{array}{c}\text { DATA DA } \\
\text { CONTRATAÇÃO }\end{array}$ & CONSTRUTORA \\
\hline Residencial Sucupira & 270 & $10.719 .000,00$ & $25 / 09 / 09$ & PDCA Engenharia \\
\hline Park dos Jacarandás I & 500 & $20.146 .321,40$ & 23/12/09 & El Global Construtora \\
\hline Park dos Jacarandás II & 498 & $20.065 .736,11$ & 23/12/09 & El Global Construtora \\
\hline Residencial Tapajós & 500 & $20.143 .508,96$ & 23/12/09 & Construtora Emcasa \\
\hline Residencial Villanueva & 500 & $20.146 .947,61$ & 23/12/09 & Castroviejo \\
\hline Residencial Villareal & 500 & $19.850 .000,00$ & 23/12/09 & Castroviejo \\
\hline Residencial Xingu & 493 & $19.863 .968,39$ & $23 / 12 / 09$ & Construtora Emcasa \\
\hline Residencial Sucesso Brasil & 141 & $5.597 .700,00$ & $23 / 12 / 09$ & Marca Registrada \\
\hline Residencial Vitória Brasil & 500 & $20.146 .952,37$ & $23 / 12 / 09$ & Marca Registrada \\
\hline Residencial Baltimore & 64 & $2.713 .804,86$ & $30 / 04 / 10$ & Marca Registrada \\
\hline Residencial Jardim Maanaim & 206 & $13.390 .000,00$ & $28 / 12 / 12$ & Castroviejo \\
\hline Residencial Tocantins I & 288 & $18.720 .000,00$ & $30 / 08 / 13$ & HLTS Incorporadora \\
\hline Residencial Tocantins II & 288 & $18.720 .000,00$ & $30 / 08 / 13$ & HLTS Incorporadora \\
\hline Residencial Córrego do Óleo I & 192 & $12.480 .000,00$ & $31 / 03 / 14$ & Marca Registrada \\
\hline Residencial Córrego do Óleo II & 288 & $18.720 .000,00$ & $31 / 03 / 14$ & Libe Construtora \\
\hline Residencial Córrego do Óleo III & 288 & $18.720 .000,00$ & $31 / 03 / 14$ & Libe Construtora \\
\hline Residencial Córrego do Óleo IV & 288 & $18.720 .000,00$ & $31 / 03 / 14$ & Libe Construtora \\
\hline Residencial Córrego do Óleo V & 256 & $16.640 .000,00$ & $31 / 03 / 14$ & Libe Construtora \\
\hline Residencial Córrego do Óleo VI & 288 & $18.720 .000,00$ & $31 / 03 / 14$ & Marca Registrada \\
\hline Residencial Monte Hebron I & 495 & $32.175 .000,00$ & $24 / 09 / 14$ & Castroviejo \\
\hline Residencial Monte Hebron II & 499 & $32.435 .000,00$ & $24 / 09 / 14$ & Castroviejo \\
\hline Residencial Monte Hebron III & 549 & $35.685 .000,00$ & $24 / 09 / 14$ & PDCA Engenharia \\
\hline Residencial Monte Hebron IV & 457 & $29.705 .000,00$ & $24 / 09 / 14$ & PDCA Engenharia \\
\hline Residencial Pequis Gleba 2A2 & 427 & $27.755 .000,00$ & $24 / 09 / 14$ & Marca Registrada \\
\hline Residencial Pequis Gleba 2A4 & 304 & $19.760 .000,00$ & $24 / 09 / 14$ & Marca Registrada \\
\hline Residencial Pequis Gleba 2A5 & 597 & $38.805 .000,00$ & $24 / 09 / 14$ & El Global Construtora \\
\hline Residencial Pequis Gleba 2A6 & 401 & $26.065 .000,00$ & $24 / 09 / 14$ & El Global Construtora \\
\hline Residencial Pequis Gleba 2B1 & 446 & $28.990 .000,00$ & $24 / 09 / 14$ & El Global Construtora \\
\hline
\end{tabular}

\footnotetext{
${ }^{4}$ Convertida na Lei ${ }^{\circ} 14.118$, de 12 de janeiro de 2021 (BRASIL, 2021).
} 


\begin{tabular}{ccrrc} 
Residencial Pequis Gleba 2B2 & 286 & $18.590 .000,00$ & $24 / 09 / 14$ & El Global Construtora \\
Residencial Pequis Gleba 2B3 & 425 & $27.625 .000,00$ & $24 / 09 / 14$ & El Global Construtora \\
Residencial Pequis Gleba 2B5 & 314 & $20.410 .000,00$ & $24 / 09 / 14$ & El Global Construtora \\
\hline TOTAL & 11548 & $652.223 .939,70$ & - & - \\
\hline
\end{tabular}

Fonte: Caixa Econômica Federal (2019). Organizado pelos autores, 2021

Em relação à localização dos conjuntos habitacionais da Faixa 1, pode-se afirmar, observando a Figura 2, que em sua grande maioria se localizam nos extremos dos setores Oeste e Sul, nas proximidades do limite do perímetro urbano de Uberlândia, evidenciando assim, a segregação socioespacial da população de baixa renda, bem como o incentivo à periferização, visto que os conjuntos são implementados em loteamentos que são previamente aprovados pela PMU.

Figura 2. Uberlândia (MG): Principais Conjuntos Habitacionais (2009-2016).

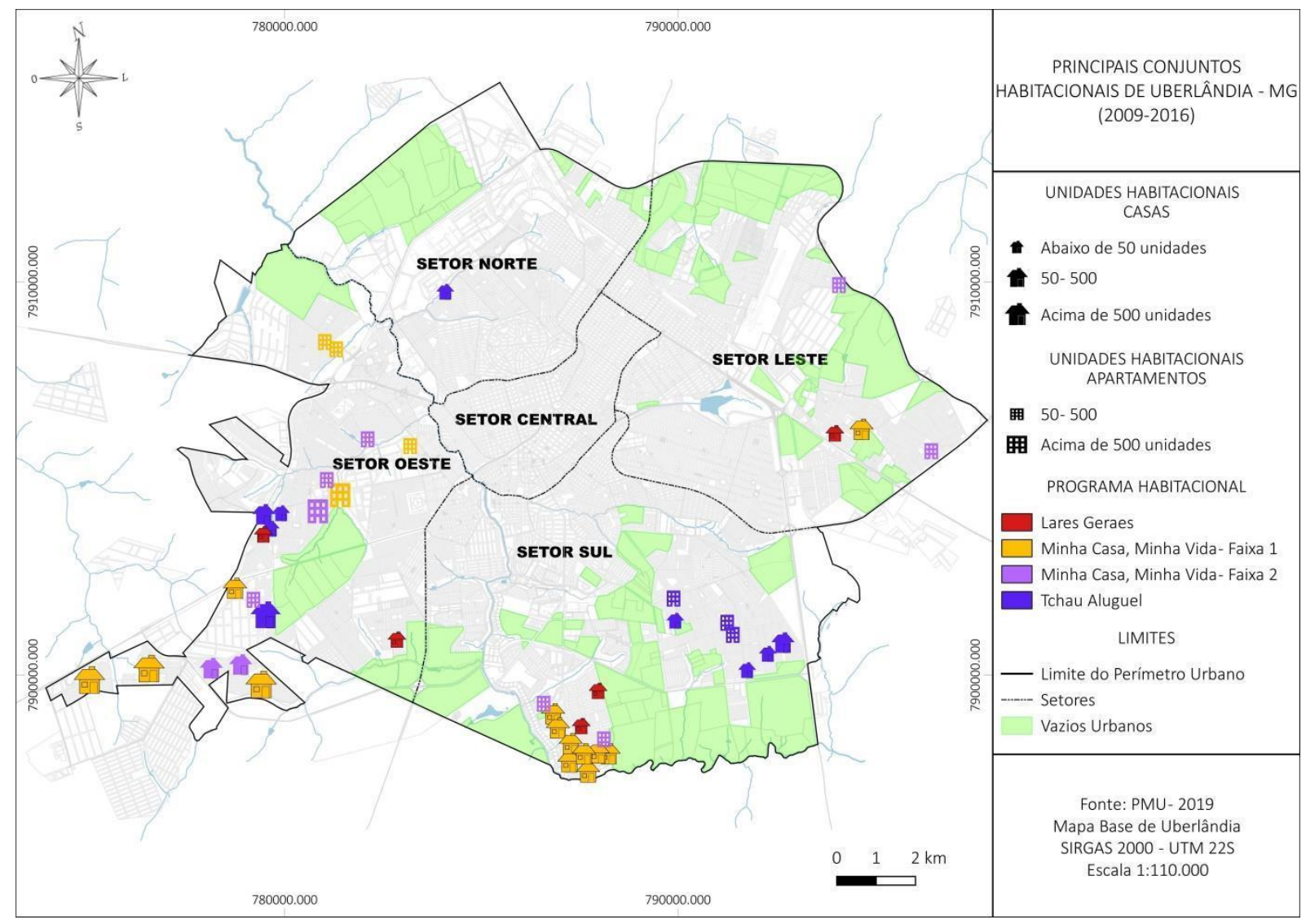

Fonte: Prefeitura Municipal de Uberlândia (2019). Elaborado pelos autores, 2021

A segregação socioespacial e a periferização, nesse caso, podem ser confirmados ao analisar a referida figura, sendo possível observar também, a quantidade de áreas não parceladas localizadas em zonas com maior centralidade no perímetro urbano de Uberlândia, comumente conhecidos como, vazios urbanos.

A respeito dos conjuntos habitacionais voltados para a Faixa 2 do PMCMV, implementados em Uberlândia, foram concebidas mais de 4300 unidades habitacionais, sendo a maioria entregue na tipologia de apartamentos. Diferentemente dos conjuntos da Faixa 1, as unidades habitacionais que são destinadas à Faixa 2 do programa, são entregues, conforme conjunto habitacional, com dois ou três quartos. Além disso, nesta modalidade, as famílias realizam um cadastro na PMU, a qual selecionará as famílias conforme requisitos preestabelecidos, classificando-as de 
acordo com a ordem de inscrição. Cabe ressaltar que na Faixa 2, as famílias conhecem o conjunto habitacional antes da assinatura do contrato, dessa forma, fica ao seu critério selecionar o conjunto que se enquadre nas suas necessidades, bem como a localização. No que se refere à localização dos conjuntos habitacionais do PMCMV Faixa 2 em Uberlândia (Figura 2), observa-se que assim como os conjuntos da Faixa 1, sua localização é majoritariamente nos setores Oeste e Sul.

$\mathrm{Na}$ Tabela 3, é possível visualizar os principais conjuntos habitacionais do PMCMV, voltados para o atendimento às famílias da Faixa 2, concebidos entre os anos de 2012 a 2016. Como dito anteriormente, os conjuntos foram concebidos em sua grande maioria, na tipologia de apartamentos.

Tabela 3. Uberlândia (MG): Conjuntos habitacionais do PMCMV - Faixa 2 (20122016).

\begin{tabular}{|c|c|c|c|c|}
\hline CONJUNTO HABITACIONAL & $\begin{array}{l}\text { NÚMERO DE } \\
\text { UNIDADES }\end{array}$ & TIPOLOGIA & $\begin{array}{c}\text { ANO DE } \\
\text { CONSTRUÇÃO }\end{array}$ & CONSTRUTORA \\
\hline Cidade Verde I * & 1776 & APARTAMENTO & 2012 & Emccamp Residencial \\
\hline Cidade Verde I - Res. Palmeira Real* & 256 & APARTAMENTO & 2013 & Realiza Construtora \\
\hline Cidade Verde $\mathrm{II}^{*}$ & 432 & APARTAMENTO & 2014 & Emccamp Residencial \\
\hline Loft Social $^{*}$ & 432 & APARTAMENTO & 2015 & Castroviejo \\
\hline Duo Park & 64 & APARTAMENTO & 2016 & Marca Registrada \\
\hline Residencial Paineiras & 192 & APARTAMENTO & 2016 & Marca Registrada \\
\hline Residencial New Golden & 192 & APARTAMENTO & 2016 & HLTS Incorporadora \\
\hline Residencial Villa Real & 192 & APARTAMENTO & 2016 & HLTS Incorporadora \\
\hline Residencial Villa Formosa & 192 & APARTAMENTO & 2016 & HLTS Incorporadora \\
\hline Residencial Lago Azul & 250 & CASA & 2016 & PDCA Engenharia \\
\hline Residencial Lago Azul & 250 & CASA & 2016 & Castroviejo \\
\hline Residencial Monte Hebron & 140 & CASA & 2016 & PDCA Engenharia \\
\hline TOTAL & 4368 & - & - & - \\
\hline
\end{tabular}

Fonte: Uberlândia (2019a). *Cidade Verde I e II; Loft Social: Pereira (2017). Organizado pelos autores, 2021

Cabe ressaltar que em Uberlândia, até o ano de 2016, não foram implementados pela PMU, conjuntos habitacionais do PMCMV voltados para a Faixa 3, possivelmente, por essa categoria possuir maior facilidade de financiamento diretamente com o agente bancário ou com as construtoras, bem como um menor déficit habitacional. Além disso, até o ano de 2018, não havia sido construído nenhum conjunto voltado para a Faixa 1,5 (UBERLÂNDIA, 2019). Frisa-se que para a Faixa 1,5 - bem como para as Faixas 2 e 3 , as famílias podem financiar o imóvel diretamente com o banco, sem a necessidade de haver inscrição prévia na PMU.

Desde a extinção do BNH até a criação do PMCMV, diversos conjuntos habitacionais de interesse social foram desenvolvidos por programas de âmbito municipal ou estadual no município de Uberlândia. Dentre eles, destacam-se os programas, Lares Geraes (estadual) e o Tchau Aluguel (municipal). Conforme a Companhia de Habitação de Minas Gerais (COHAB/MG, 2020), o Lares Geraes/Habitação Popular (PLHP), é um programa de Habitação de Interesse Social (HIS) que possui como objetivo, reduzir o déficit habitacional em Minas Gerais, oferecendo moradias subsidiadas às famílias com renda de 1 a 3 salários-mínimos. Segundo Pereira (2017), o Residencial Parque Santo Antônio, construído em 2010, foi o último conjunto habitacional construído no município de Uberlândia através do programa Lares Geraes. 
O Tchau Aluguel trata-se, na verdade, de um Plano Municipal de Habitação ${ }^{5}$, instituído pela Lei no 9080, de 25 de outubro de 2005, e, que possui como objetivos ofertar casas ou apartamentos, bem como terrenos urbanizados e material de construção aos inscritos.

Conforme Art. 4º , da Lei nº 9080/2005, os programas de HIS do Tchau Aluguel, são executados:

I - mediante aplicação de recursos do Fundo Municipal de Habitação e outras dotações orçamentárias municipais;

II - com participação em programas desenvolvidos pela Caixa Econômica Federal, bancos privados ou por outros organismos financiadores;

III - mediante convênios com instituições privadas que se disponham a oferecer imóveis à população de baixa renda dentro das condições exigidas pelo município;

IV - quaisquer outras rendas eventuais;

$\mathrm{V}$ - mediante regime de mutirão habitacional, cooperativismo, empreitada, autoconstrução ou iniciativa do mutuário (UBERLÂNDIA, 2005).

Além disso, o programa atuou entre os anos de 2005 a 2012, sendo posteriormente retomado em 2017, em parceria com a CEF, na concepção de moradias para famílias com renda de até $R \$ 2.600,00$ (UBERLÂNDIA, 2020).

$\mathrm{Na}$ Tabela 4, estão representados os principais conjuntos habitacionais de interesse social concebidos em Uberlândia, através dos programas Tchau Aluguel e Lares Geraes, construídos entre os anos de 2009 a $2012^{6}$.

Tabela 4. Uberlândia (MG): Principais conjuntos habitacionais construídos pelos programas Tchau Aluguel e Lares Geraes (2009-2012).

\begin{tabular}{lcccc}
\hline \multicolumn{1}{c}{ BAIRRO } & $\begin{array}{c}\text { NÚUERO DE } \\
\text { UNIDADES }\end{array}$ & TIPOLOGIA & $\begin{array}{c}\text { ANO DE } \\
\text { CONSTRUÇA }\end{array}$ & PROGRAMA \\
\hline Seringueiras & 60 & CASA & $2009 / 2010$ & Tchau Aluguel \\
Parque São Gabriel & 18 & CASA & $2009 / 2010$ & Tchau Aluguel \\
Jardim Célia & 1136 & CASA & $2009 / 2010$ & Tchau Aluguel \\
Jardim Europa & 74 & CASA & $2009 / 2010$ & Lares Geraes \\
Jardim das Palmeiras & 46 & CASA & $2009 / 2010$ & Lares Geraes \\
Shopping Park II & 80 & CASA & $2009 / 2010$ & Lares Geraes \\
Jardim Sucupira & 18 & CASA & $2009 / 2010$ & Lares Geraes \\
Parque Santo Antônio & 44 & CASA & $2009 / 2010$ & Lares Geraes \\
Laranjeiras & 144 & APARTAMENTO & $2009 / 2010$ & Tchau Aluguel \\
Jardim Europa & 10 & CASA & $2009 / 2010$ & Tchau Aluguel \\
Residencial Campo Alegre & 39 & CASA & $2009 / 2010$ & Tchau Aluguel \\
Parque São Jorge I & 176 & APARTAMENTO & $2009 / 2010$ & Tchau Aluguel \\
Maravilha & 37 & CASA & 2011 & Tchau Aluguel \\
Jardim Veneza & 18 & CASA & 2011 & Tchau Aluguel \\
Parque São Jorge II & 176 & APARTAMENTO & 2012 & Tchau Aluguel \\
\hline \multicolumn{1}{c}{ TOTAL } & 2076 & - & - & - \\
\hline
\end{tabular}

Fonte: Pereira (2017). Organizado pelos autores, 2021

Nota-se que a maioria dos conjuntos (exceto Jardim Célia), possui como característica o baixo número de unidades habitacionais, além de serem concebidos em sua maioria em bairros com infraestrutura já existente. Este número reduzido de

\footnotetext{
${ }^{5}$ Porém, é comumente mencionado como "programa" em documentos oficiais da Prefeitura Municipal de Uberlândia (PMU). Portanto, neste artigo foi utilizado o vocábulo "programa" às referências ao Tchau Aluguel.

${ }^{6}$ Este recorte deveu-se à concomitância dos referidos programas com o PMCMV, que foi lançado em 2009.
} 
unidades habitacionais por conjunto possibilitou que os referidos projetos fossem construídos em áreas já urbanizadas, ao contrário de conjuntos com muitas unidades, como foi o caso do bairro Jardim Célia.

$\mathrm{Na}$ Figura 2 é possível observar a espacialidade dos principais conjuntos habitacionais implementados em Uberlândia, entre os anos de 2009 a 2016, pelos programas MCMV, Tchau Aluguel e Lares Geraes, em contraste com os vazios urbanos localizados no perímetro urbano da cidade.

Além disso, como foi possível observar na Figura 2, entre os anos de 2009 e 2016, foram construídos conjuntos habitacionais em todos os setores de Uberlândia, exceto no Setor Central. Além disso, destaca-se que em sua grande maioria estão localizados nas extremidades dos setores, sobretudo Oeste e Sul, adjacentes ao limite do perímetro urbano.

Outra constatação possível é a de que, geralmente, os conjuntos habitacionais construídos na tipologia de apartamentos possuem melhor localização em relação ao de casas, independente se são voltados para a Faixa 1 ou 2 dos programas habitacionais. Isso também fica evidente nos conjuntos de casas, porém, naqueles com menos de 50 unidades habitacionais. Possivelmente, isso decorre do fato de necessitarem de uma menor área para implementação, o que possibilita estarem localizados em zonas com infraestrutura previamente existente.

Em relação à comparação da espacialidade entre os conjuntos da Faixa 1 e 2, não ficou constatado se possuem grande diferença de localização. Entretanto, ressalta-se que no caso das famílias da Faixa 2, elas conhecem a localização dos conjuntos habitacionais, bem como sua infraestrutura antes da assinatura do contrato, prerrogativa inexistente às famílias da Faixa 1. Dessa forma, em relação às famílias da Faixa 2, evidencia-se apenas a segregação socioespacial na forma induzida, o que não é imposto, como às famílias da Faixa 1.

Entretanto, é notável a existência de grandes vazios urbanos localizados dentro da área do perímetro urbano de Uberlândia, fruto da especulação imobiliária exercida pelo mercado imobiliário e financeiro, e do monopólio fundiário de determinados grupos sociais e empresas. Isso ratifica a afirmação de Carlos (2014, p. 60) de que: "a produção do espaço se insere na lógica da produção capitalista que transforma toda a produção em mercadoria", pois, fica evidente que os conjuntos habitacionais, sejam eles na tipologia de apartamentos ou casas, são implementados, sobretudo, em zonas periféricas da cidade (como se constatou na referida Figura 2), cuja gestão e implementação são realizadas pelo poder público local, que em acordo com a legislação por ele mesmo criada, torna-se parceiro do empreendedor imobiliário, que deseja sempre obter o maior lucro possível do empreendimento realizado.

\section{LEGISLAÇÃO E SEGREGAÇÃO SOCIOESPACIAL EM UBERLÂNDIA- MG: INFLUÊNCIA DO SETOR PÚBLICO NA DEFESA DE INTERESSES PRIVADOS NA ESCOLHA DE LOCALIZAÇÃO DE CONJUNTOS HABITACIONAIS}

O Art. 182 da Constituição Federal (CF), de 1988, que trata da Política Urbana nos municípios brasileiros, define que a política de desenvolvimento urbano deve, seguindo as diretrizes previstas em lei, objetivar as funções sociais da cidade, nesse caso, a função social da propriedade urbana. Além disso, assegura caso seja de interesse do poder público municipal, a prerrogativa de desapropriar propriedades urbanas que se encontrem em situação de não edificação/utilização ou subutilização 
(BRASIL, 1988). Ou seja, o solo urbano que não esteja cumprindo sua função social, pode ser passível, conforme o referido artigo, de:

I - parcelamento ou edificação compulsórios;

II - imposto sobre a propriedade predial e territorial urbana progressivo no tempo;

III - desapropriação com pagamento mediante títulos da dívida pública de emissão previamente aprovada pelo Senado Federal, com prazo de resgate de até dez anos, em parcelas anuais, iguais e sucessivas, assegurados o valor real da indenização e os juros legais (BRASIL, 1988, não paginado).

Contudo, esse capítulo da CF que trata da Política Urbana serviu apenas como base legal na discussão da temática. No entanto, é na Lei 10.257, de 10 de julho de 2001, a do Estatuto da Cidade, que regulamenta a orientação aos municípios na elaboração dos planos diretores previstos no referido capítulo. O parágrafo único do Estatuto da Cidade, "estabelece normas de ordem pública e interesse social que regulam o uso da propriedade urbana em prol do bem coletivo, da segurança e do bem-estar dos cidadãos, bem como do equilíbrio ambiental" (BRASIL, 2001, não paginado). Dessa forma, a regulamentação dos artigos 182 e 183 da CF, buscou estipular as diretrizes e a execução das políticas urbanas nos municípios brasileiros, sob a premissa da função social da propriedade. Além disso, o Estatuto da Cidade prevê a gestão democrática da cidade com participação popular através de audiências e consultas públicas, por exemplo.

Segundo o Art. 4ํㅜ, incisos III e V do Estatuto da Cidade, dentre estes instrumentos que podem ser instituídos em âmbito municipal, destacam-se, por exemplo: o plano diretor; as leis de parcelamento, de ocupação e uso do solo e de zoneamento ambiental; os instrumentos jurídicos de desapropriação; a instituição de Zonas Especiais de Interesse Social (ZEIS); o Parcelamento, Edificação ou Utilização Compulsória (PEUC); e, a regularização fundiária (BRASIL, 2001). Dessa forma, esses instrumentos devem, ou, pelo menos, deveriam, através do estabelecimento de leis municipais, serem utilizados pelo poder público municipal no propósito de evitar, por exemplo, a segregação socioespacial da população de baixa renda, o processo de periferização e a especulação imobiliária.

Ainda conforme o Estatuto da Cidade, o poder público municipal possui a prerrogativa de instituir através do plano diretor ou de outra legislação específica, a utilização compulsória de áreas não parceladas ou não edificadas situadas em perímetro urbano, como preconizado pela CF. Nesse caso, uma vez a lei específica promulgada, o poder público municipal deve notificar os proprietários de áreas que se enquadrem na condição de não edificada/utilizada ou subutilizada, estabelecendo o prazo de um ano para a apresentação de um projeto de parcelamento ou edificação no órgão municipal competente, e o prazo de dois anos para a execução do projeto. Caso os proprietários notificados não cumpram com a legislação, o poder público pode, nesse caso, aplicar ao proprietário o IPTU progressivo no tempo, que consiste no aumento sucessivo da alíquota do imposto pelo prazo de cinco anos. Decorrendo esse prazo, o poder público municipal, pode ou não, seguindo a legislação municipal, aplicar a desapropriação com pagamento mediante emissão de títulos da dívida pública. Na prática, o que se intenta com a aplicação desses instrumentos, entre outros objetivos é a inibição da especulação imobiliária, a não segregação socioespacial, a não expansão irracional do tecido urbano das cidades, a mitigação 
do processo de periferização, bem como o cumprimento da função social da cidade e da propriedade urbana.

Embora a regulamentação do Art. $182^{\circ}$ da Constituição Federal tenha sido promulgada em 2001 com o Estatuto da Cidade, em Uberlândia a instituição dos instrumentos compulsórios, somente ocorreu com a promulgação do Plano Diretor de 2006 (UBERLÂNDIA, 2006), entretanto, o Art. 47, que institui o PEUC, somente foi regulamentado em 2011 com a Lei Complementar Municipal no 521/2011 ${ }^{7}$ (UBERLÂNDIA, 2011), que foi posteriormente alterada pela Lei Complementar n 640, de 5 de janeiro de 2018.

Dessa forma, entre as modificações ocorridas nas referidas leis, as principais foram: as definições de solo urbano não edificado, de vazio urbano e de lote vago no Art. $2^{\circ}$ (Lei Complementar n 640/2018); na definição de vazios urbanos, que passou de áreas superiores a $6.000 \mathrm{~m}^{2}$ para $20.000 \mathrm{~m}^{2}$; e, na ampliação de $2.000 \mathrm{~m}^{2}$ para $8.000 \mathrm{~m}^{2}$ para aplicação das medidas de compulsoriedade aos proprietários de lotes vagos, contíguos ou não, no perímetro urbano. Além disso, o então prefeito eleito para a gestão 2017-2020, alegou que por negligência da gestão municipal anterior, que não havia cumprido os prazos estabelecidos pela legislação para a implantação do IPTU progressivo, foi necessário renovar a lei com novos prazos (TORRES, 2017). Entretanto, esta nova promulgação através da Lei Complementar nํ 640/2018, revogou todas as notificações realizadas em 2016, aos proprietários que possuíam imóveis passíveis da aplicação dos instrumentos compulsórios, dessa forma, aumentando o prazo, para que os proprietários apresentassem um projeto de parcelamento ou edificação (UBERLÂNDIA, 2018), ou seja, ficou evidente que os proprietários haviam sido notificados. Lembrando que segundo dados da PMU, veiculados no MGTV 2 ${ }^{\text {a }}$ Edição ${ }^{8}$, em 2017, havia em Uberlândia 12.789 imóveis em situação de não edificação/utilização ou subutilizados, sob a posse de 1.124 proprietários (MGTV, 2017).

Dessa forma, as notificações somente ocorreram após a promulgação da Portaria $n^{\circ}$ 49.512, de 09 de junho de 2020, que "dispõe sobre os procedimentos administrativos a serem implementados para fins de cumprimento da Lei Complementar $n^{\circ} 521$, de 16 de fevereiro de 2011 e suas alterações" (UBERLÂNDIA, 2020a, p. 2). Lembrando que após a notificação por parte da PMU, o proprietário do imóvel que não esteja cumprindo a função social teria um ano para apresentar algum projeto de utilização, ou seja, desde a promulgação do Estatuto da Cidade, em julho de 2001, até ao efetivo prazo para a utilização ou parcelamento das áreas, se passariam praticamente 20 anos. Portanto, fica evidente como o poder público se utiliza de mecanismos que postergam o cumprimento da função social da propriedade urbana, beneficiando assim os proprietários fundiários urbanos que, muitas vezes, mantém a posse de grandes áreas em perímetro urbano com o propósito de obter lucros a partir da especulação imobiliária.

Em relação à Lei de Parcelamento e Zoneamento do Uso e Ocupação do Solo de 1999 (Lei Complementar no 224, de 23 de dezembro de 1999), um aspecto importante a ser ressaltado, é o fato de haver uma proibição ${ }^{9}$ no estabelecimento de

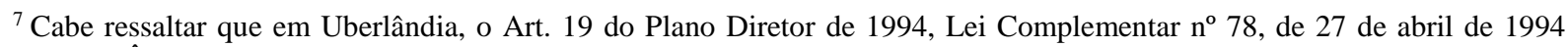
(UBERLÂNDIA, 1994), já fazia referência aos instrumentos compulsórios, porém não foram aplicados por falta de regulamentação federal específica que, no caso, somente ocorreu com a promulgação do Estatuto da Cidade.

8 Telejornal Local produzido pela TV Integração, afiliada da Rede Globo no Triângulo Mineiro. Disponível em: <http://g1.globo.com/minas-gerais/triangulo-mineiro/mgtv-2edicao/videos/v/camara-aprova-iptu-progressivo-emuberlandia/6357871/>.

${ }_{9}^{9}$ Conforme, Anexo VI - Tabela 1, Quadro de Adequação dos Usos às Zonas da Lei Complementar nº 224, de 23 de dezembro de 1999. (UBERLÂNDIA, 1999).
} 
áreas voltadas para a HIS, onde, segundo o Art. 52: "Considera-se Zona Residencial 1 (ZR1) a região sul da cidade, a qual acomoda a função habitacional de forma mais restrita e de menor densidade que as demais" (UBERLÂNDIA, 1999, não paginado). Ou seja, em boa parte do Setor Sul da cidade de Uberlândia, é proibido a construção de unidades de HIS. Conforme aponta Silva (2012): "A área da ZR1 é ocupada pela parcela mais elitizada da cidade e, consequentemente, do setor Sul. Nela encontramse essencialmente residências e comércios de luxo, destinados a atender as necessidades da população local que detém aspirações diferenciadas" (SILVA, 2012, p. 74). Dessa forma, evidencia-se a institucionalização da segregação socioespacial, tendo em vista que a legislação deveria ser utilizada para alcançar a função social da cidade, entretanto, é, na verdade, utilizada como instrumento de exclusão e expulsão da população de baixa renda, mesmo que indiretamente, para áreas periféricas da cidade, denominadas na referida legislação de zona de expansão urbana (UBERLÂNDIA, 1999). A respeito disso, Villaça (2011) leciona que:

Ao comandar a produção do espaço urbano, a classe dominante comanda não só a sua produção material e direta, seu valor e seu preço (comandando o mercado imobiliário). Comanda também as ações do Estado sobre esse espaço (legislação urbanística, localização dos aparelhos de Estado, produção do sistema de transportes etc.) e ainda a produção das ideias dominantes a respeito dele. Tudo isso na verdade é o que especifica o espaço urbano (VILLAÇA, 2011, p. 53).

Cabe destacar que embora a Lei Complementar no 224/1999 tenha sido revogada, a proibição de construção de HIS na então ZR1, ainda perdura nas sucessivas leis de zoneamentos de usos do solo (UBERLÂNDIA, 2000; 2011b; 2019a; 2019b). Além disso, conforme consta no Art. 7ํㅜㄹ inciso VII, da Lei Complementar $n^{\circ}$ 523, de 7 de abril de 2011: "Não será permitido o parcelamento do solo [...] em novas áreas, quando não contíguas à mancha urbana já parcelada, salvo para estabelecimento, pelo poder público, de Zonas Especiais de Interesse Social - ZEIS, autorizadas em leis específicas" (UBERLÂNDIA, 2011a, não paginado). Portanto, de acordo com a legislação municipal uberlandense, o poder público é autorizado a instituir as ZEIS em áreas não contíguas do tecido urbano, evidenciando, novamente, o caráter segregador da legislação.

Dessa forma, no ano de 2013, com o objetivo de implementar novos conjuntos habitacionais do Programa Minha Casa, Minha Vida (PMCMV), sendo eles, os residenciais Pequis, Monte Hebron, Lago Azul e Fruta do Conde, no Setor Oeste, a PMU através da Lei Municipal no 11.412, de 19 de junho de 2013, estabeleceu uma nova demarcação do perímetro urbano para a sede do município, revogando a Lei no 10.575, de 20 de setembro de 2010 (UBERLÂNDIA, 2010; 2013). Na Figura 3, é possível observar a localização periférica das novas glebas incorporadas ao perímetro urbano, que contrastam com grandes vazios urbanos. Destaca-se que para acesso aos residenciais Pequis, Lago Azul e Monte Hebron é necessário passar ao lado de um desses vazios urbanos. 
Figura 3. Uberlândia (MG): Glebas Incorporadas ao Perímetro Urbano - 2013.

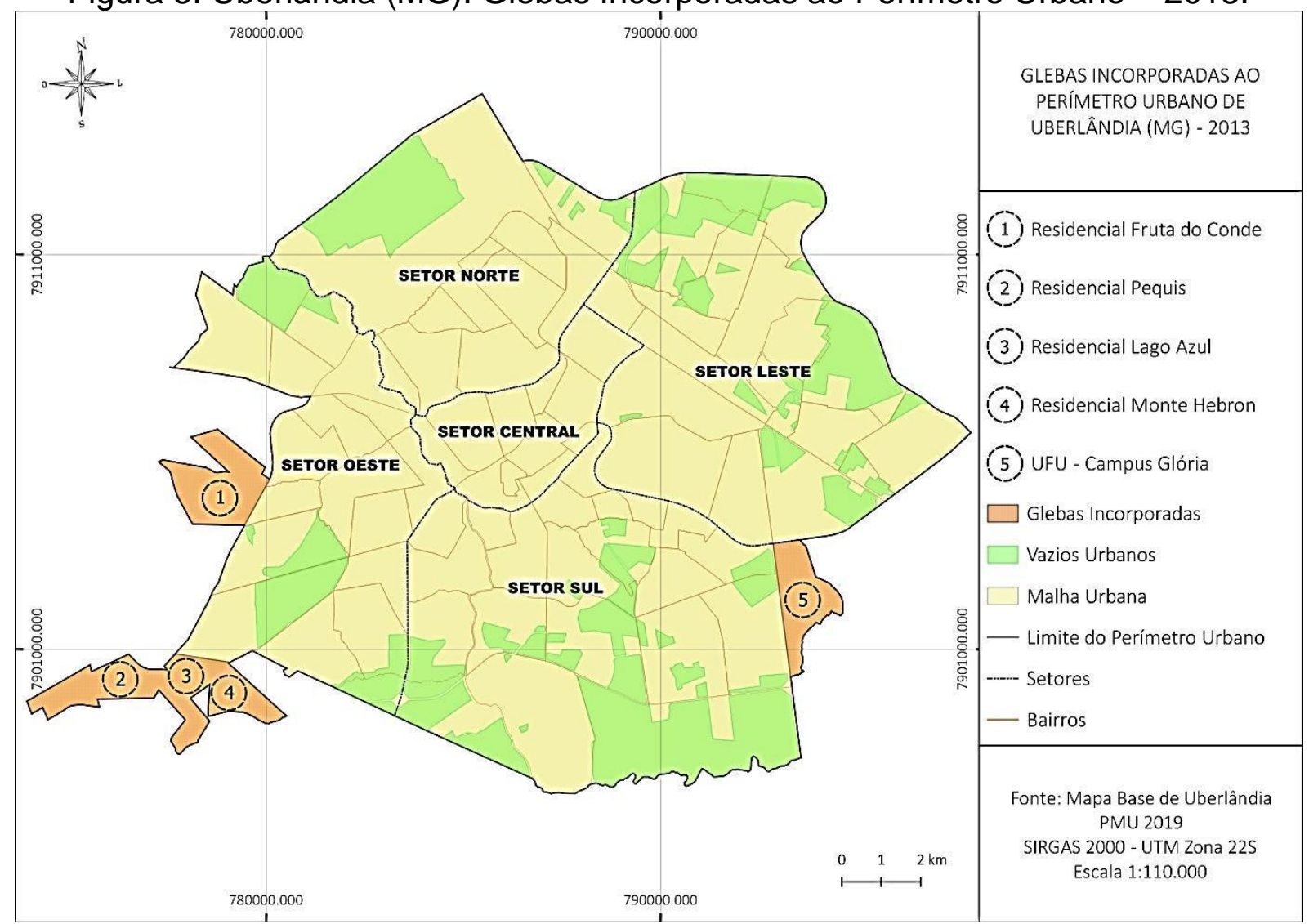

Fonte: Prefeitura Municipal de Uberlândia (2019). Elaborado pelos autores, 2021

Em 2013, o então empresário e representante do Sindicato da Habitação do Triângulo Mineiro e Alto Paranaíba (SECOVI - TAP), informou ao então prefeito que não havia áreas dentro do perímetro urbano para a construção dos referidos conjuntos habitacionais devido ao custo das áreas, sugerindo então, que houvesse a alteração do perímetro urbano (G1 - Triângulo, 2013). Dessa forma, posteriormente a alteração dos limites do perímetro urbano, a PMU instituiu através da Lei Complementar oㅡ 567, de $1^{\circ}$ de julho de 2013, Art. 3으, as Zonas Especiais de Interesse Social IV (ZEIS IV) de áreas não parceladas, com o objetivo de reservar para a HIS o mínimo 1/3 (um terço) da área loteável das novas glebas integradas ao perímetro urbano (UBERLÂNDIA, 2013a).

Entretanto, é questionável se realmente houve a necessidade da inclusão de novas áreas na zona urbana, visto que, conforme aponta Motta (2015) com base no mapa base da PMU, em 2015, o perímetro urbano da cidade correspondia à aproximadamente $235 \mathrm{~km}^{2}$, dos quais aproximadamente $95 \mathrm{~km}^{2}$ eram representados por vazios urbanos, cerca de $40 \%$ da área urbana da cidade. Além disso, apenas seis meses antes da contratação dos conjuntos habitacionais nos residenciais Pequis e Monte Hebron, houve a contratação de 1600 unidades na tipologia de apartamentos, localizadas no Residencial Córrego do Óleo, também no Setor Oeste, voltadas para a Faixa 1 do PMCMV, em que o conjunto foi concebido em região previamente urbanizada, dotado de toda infraestrutura. Evidencia-se, dessa forma, um contrassenso, pois, conforme o Art. $2^{\circ}$ do Estatuto da Cidade, "[...] A política urbana tem por objetivo ordenar o pleno desenvolvimento das funções sociais da cidade e da propriedade urbana [...]", afirmando no Inciso $\mathrm{VI}$, que busca evitar através da ordenação e controle do uso do solo: "[...] a) a utilização inadequada dos imóveis 
urbanos [...] e) a retenção especulativa de imóvel urbano, que resulte na sua subutilização ou não utilização [...]" (BRASIL, 2001).

Além disso, através da Lei Complementar № 679, de 3 de junho de 2019, o poder público municipal institui e delimita sete Zonas de Urbanização Específica (ZUE) (UBERLÂNDIA, 2019c), sendo elas:
a) ZUE 6 - Setor Mansour V;
b) ZUE 7 - Setor Monte Sinai;
c) ZUE 8 - Setor São Bento II;
d) ZUE 9 - Setor Mansour IV;
e) ZUE 10 - Setor Parque Santo Antônio III;
f) ZUE 11 - Setor Pôr do Sol;
g) ZUE 12 - Setor Olhos d'Água.

Dessa forma, conforme a referida lei, as novas áreas foram delimitadas com o objetivo de serem utilizadas na implantação de unidades habitacionais, na tipologia de casas, em lotes de no mínimo $200 \mathrm{~m}^{2}$, pelo Programa Habitacional Tchau Aluguel. Além disso, reserva-se o percentual mínimo de $70 \%$ da área loteável de cada ZUE para tal finalidade (UBERLÂNDIA, 2019c). Sendo assim, constata-se através da Figura 4, que a maioria das áreas, encontram-se adjacentes ao Setor Oeste, com exceção ao Setor Olhos d'Água, que está localizado nas proximidades do Setor Leste, em área descontínua ao tecido urbano.

Portanto, novamente reforça-se o caráter segregacionista dos programas habitacionais de interesse social, visto que as novas áreas, pertencentes à zona rural, serão integradas ao perímetro urbano da cidade, com o objetivo de comportar novos conjuntos habitacionais, enquanto imensos vazios urbanos permanecem intocáveis à espera de valorização imobiliária. Nesse sentido, Carlos (2007) afirma que:

É, portanto, um meio e um poder nas mãos de uma classe dominante que diz representar a sociedade, sem abdicar de objetivos próprios de dominação, usando como meio às políticas públicas para direcionar e regularizar fluxos, centralizando, valorizando/desvalorizando os lugares através de intervenções como "ato de planejar". Nessa condição, o espaço se pretende homogêneo (pela dominação) e hierarquizado (pela divisão espacial do trabalho). Como produto, deparamo-nos com o espaço da norma e da vigilância: um espaço estratégico" (CARLOS, 2007, p. 52). 
Figura 4. Uberlândia (MG): Zonas de Urbanização Específica (ZUE) - 2019.

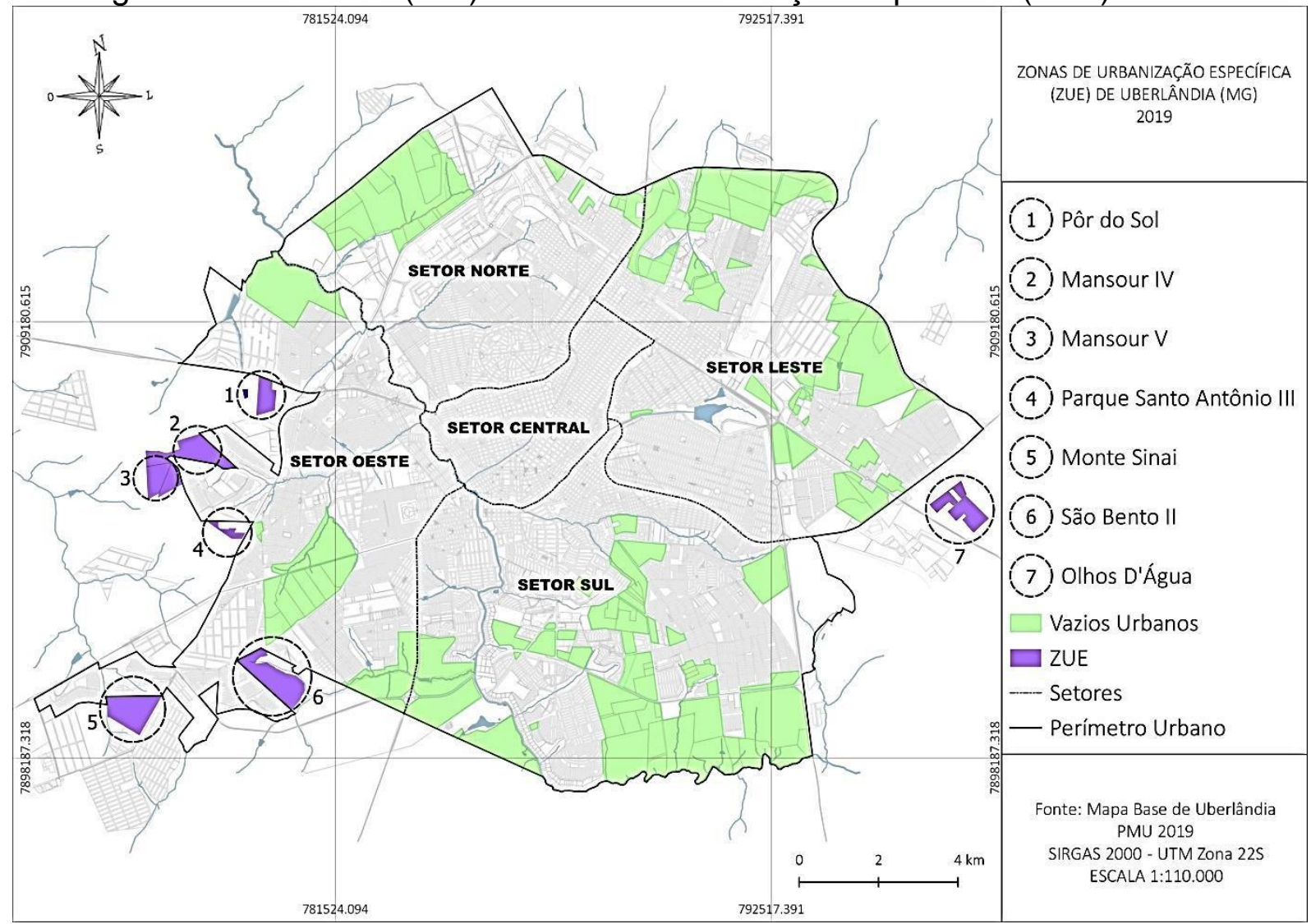

Fonte: Prefeitura Municipal de Uberlândia (2019). Elaborado pelos autores, 2021.

Como foi possível compreender, as aplicações das premissas do Estatuto da Cidade no município de Uberlândia, se demonstraram até o momento pouco eficientes, considerando o adiamento na implementação do PEUC da propriedade urbana, bem como do IPTU progressivo no tempo. Dessa forma, os proprietários fundiários passam a ter um prazo maior para a destinação de suas respectivas áreas que não cumprem a função social. Como consequência, o poder público local passa a implementar através das leis de zoneamento, as ZEIS ou ZUE na zona rural do município, em área denominada de zona de expansão urbana, com o objetivo de utilizá-las na implantação de conjuntos habitacionais de interesse social. Ou seja, evidencia-se uma vantagem concedida aos grupos sociais que possuem os títulos de posse dos vazios urbanos na cidade de Uberlândia, em detrimento da população de baixa renda que, por não conseguirem acesso à casa própria por financiamento diretamente com o agente financeiro ou com as construtoras, acabam expostas à segregação socioespacial imposta pela implementação de tais conjuntos de interesse social em regiões periféricas da cidade.

Além disso, ficou evidente como determinados grupos sociais, respaldados pelo poder público local, logram através da legislação municipal, a exclusão social de determinados grupos sociais como, por exemplo, a restrição de implementação de conjuntos habitacionais em determinados setores da cidade, que são ocupados pela população de maior poder aquisitivo, ou, também, como empreendedores da construção civil, são capazes de influenciar o poder público, no que se refere à localização dos conjuntos habitacionais, defendendo assim, seus próprios interesses. 


\section{CONSIDERAÇÕES FINAIS}

Este estudo consistiu em analisar e compreender o processo de segregação socioespacial na cidade de Uberlândia-MG, a partir dos conjuntos habitacionais. Foi possível analisar de que forma o mercado imobiliário e as construtoras atuam e se apropriam dos programas habitacionais de interesse social, bem como estes atuam juntos ao poder público local no que concerne à localização e disposição geográfica deles em relação ao conjunto da cidade, evidenciando a prevalência dos interesses de mercado sobre a função social da propriedade.

Dessa forma, ao se estudar a localização dos conjuntos habitacionais construídos em Uberlândia entre os anos de 2009 e 2016, sejam eles desenvolvidos no âmbito do Programa Minha Casa, Minha Vida (PMCMV), Tchau Aluguel ou Lares Geraes, foi possível observar que em sua grande maioria estão localizados nos setores Sul e Oeste da cidade (em menor medida nos setores Leste e Norte), o que faz sentido, visto que são os setores que representam os vetores de crescimento preferenciais da cidade, conforme direcionamento do Plano Diretor. Além disso, destaca-se que são nos setores Sul e Oeste, bem como no Setor Leste, que se encontram a maior parte dos vazios urbanos em Uberlândia. Nota-se que os conjuntos habitacionais construídos na tipologia de apartamentos ou conjuntos de casas que possuem até 50 unidades habitacionais, tendem a se localizar em regiões previamente urbanizadas, logicamente, por necessitarem de menor área para implementação, ao contrário de grandes conjuntos como, por exemplo, o Jardim Célia e o Residencial Pequis. Nesse sentido, ressalta-se que grandes conjuntos se tornam grandes ativos políticos, visto que são comumente utilizados para dar visibilidade e moeda de troca de voto a eles, em época de campanha eleitoral.

Em relação à diferença de localização dos conjuntos habitacionais, levando em consideração as faixas de rendas (Faixa 1 e 2), para o período verificado (2009-2016), não ficou evidente que possuem grandes disparidades, porém, cabe ressaltar que para as famílias inscritas na Faixa 1 dos programas, ou seja, aquelas de menor renda, não é possível escolher, por parte dos proponentes, a localização do conjunto que melhor atenda às suas necessidades, evidenciando a "segregação socioespacial imposta", ao passo que para as famílias que se enquadram na Faixa 2, existe a possibilidade de escolha do empreendimento que melhor se enquadre às suas necessidades, portanto, caracterizando como uma "segregação socioespacial induzida", visto que a maior parte dos conjuntos para esta faixa se localizam nas regiões periféricas da cidade. Ressalta-se que para esta faixa de renda, não necessariamente existe o intermédio da prefeitura, dessa forma, possibilitando que o proponente financie sua moradia diretamente com a construtora ou com o agente financeiro.

A regulamentação das leis de parcelamento, edificação ou da utilização compulsórios (PEUC) e, também, do Imposto Predial e Territorial Urbano (IPTU) progressivo no tempo, em Uberlândia, ocorreram de forma lenta e controversa. Embora o Estatuto da Cidade tenha sido promulgado em 2001, tais instrumentos somente foram implementados no Plano Diretor Municipal de 2006. Desde então, destacam-se várias alterações na legislação municipal que acabaram por postergar a aplicação dos instrumentos como, por exemplo, as modificações nas definições de solo urbano não edificado, de vazio urbano e de lote vago, além da postergação na aplicação do IPTU progressivo no tempo, que foi implementado apenas em 2018, através da Lei Complementar nำ640/2018, e sua aplicação somente em junho de 2020, através do Decreto no 49.512/2020. Dessa forma, o poder público municipal, 
contribui para a manutenção da especulação imobiliária, visto que essa postergação beneficia os proprietários dos grandes vazios urbanos de Uberlândia, reverberando na segregação socioespacial e periferização das famílias que não possuem condições de adquirir uma moradia no mercado imobiliário formal.

Nesse sentido, cabe destacar também, em relação à legislação uberlandense, a alteração do perímetro urbano da cidade, ocorrida em 2013, com a justificativa de que não havia áreas viáveis (do ponto de vista do mercado imobiliário) para a implementação de conjuntos habitacionais do PMCMV, após a sugestão de um empresário do ramo imobiliário e então presidente do Sindicato da Habitação do Triângulo Mineiro e Alto Paranaíba (SECOVI - TAP). Portanto, fica evidente a maneira como empresários, sejam eles, da construção civil ou do mercado imobiliário, influenciam/fornecem diretrizes ou participam ativamente da vida política de Uberlândia, defendendo, dessa forma, seus interesses.

\section{REFERÊNCIAS BIBLIOGRÁFICAS}

AMORE, Caio Santo. "Minha Casa Minha Vida" para iniciantes. In: AMORE, Caio Santo; SHIMBO, Lúcia Zanin; RUFINO, Maria Beatriz Cruz (Orgs.). Minha casa... e a cidade? Avaliação do programa minha casa minha vida em seis estados brasileiros. Rio de Janeiro: Letra Capital, 2015. p. 11-27.

BERNARDO, Luciano Tiago. A classe média brasileira no século XXI e sua relação com o Programa Minha Casa, Minha Vida (PMCMV): reflexões a partir de Uberlândia (MG). 2018. 280 f. Tese (Doutorado em Geografia) - Instituto de Geografia, Universidade Federal de Uberlândia, Uberlândia, 2018.

BRASIL. Constituição (1988). Constituição da República Federativa do Brasil. [online].Brasília, DF: Senado Federal: Centro Gráfico, 1988. Disponível em: <http://www.planalto.gov.br/ccivil_03/constituicao/constituicao.htm>.

Lei no 10.257 de 10 de julho de 2001. Regulamenta os arts. 182 e 183 da Constituição Federal, estabelece diretrizes gerais da política urbana e dá outras providências.

Disponível

em: <http://www.planalto.gov.br/ccivil_03/LEIS/LEIS_2001/L10257.htm>. Acesso em: 07 jul. 2020.

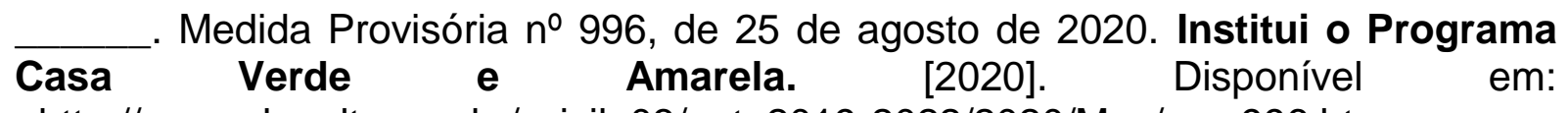
<http://www.planalto.gov.br/ccivil_03/_ato2019-2022/2020/Mpv/mpv996.htm>.

Acesso em: 02 jan. 2021.

Lei $\mathrm{n}^{\circ}$ 14.118, de 12 de janeiro de 2021. Institui o Programa Casa Verde e Amarela; altera as Leis $\mathrm{n}$ - 8.036, de 11 de maio de 1990, 8.100, de 5 de dezembro de 1990, 8.677, de 13 de julho de 1993, 11.124, de 16 de junho de 2005, 11.977, de 7 de julho de 2009, 12.024, de 27 de agosto de 2009, 13.465, de 11 de julho de 2017, e 6.766, de 19 de dezembro de 1979; e revoga a Lei no 13.439, de 27 de abril de 2017. Disponível em: <http://www.planalto.gov.br/ccivil_03/_Ato20192022/2021/Lei/L14118.htm>. Acesso em: 11 fev. 2021. 
CARLOS, Ana Fani Alessandri. Diferenciação socioespacial. Cidades, Presidente Prudente, v. 4, n. 6, p. 45-60, 2007.

Da "organização" à "produção" do espaço no movimento do pensamento geográfico. In: CARLOS, Ana Fani; SOUZA, Marcelo Lopes de; SPOSITO, Maria Encarnação (Org.). A Produção do espaço urbano: agentes, escalas e desafios. 1.ed., 3 reimpressão. - São Paulo: Contexto, 2014. p. 53-73.

CEF - CAIXA ECONÔMICA FEDERAL. Empreendimentos MCMV. Publicado em: 10 Jul. 2019. [Planilha Excel]. Disponível em: <http://www.caixa.gov.br/Downloads/habitacao-minha-casa-minhavida/Empreendimentos_MCMV.zip>. Acesso em: 08 jul.2020.

COHAB/MG - Companhia de Habitação do Estado de Minas Gerais. Companhia de Habitação do Estado de Minas Gerais - Apresentação. Disponível em: <http://www.cohab.mg.gov.br/apresentacao-4/>. Acesso em: 08 jul. 2020.

CORRÊA, Roberto Lobato. Segregação Residencial: Classes Sociais e Espaço Urbano. In. CORRÊA, Roberto Lobato; PINTAUDI, Silvana Maria; VASCONCELOS, Pedro de Almeida (Orgs.). A cidade contemporânea: segregação espacial. São Paulo: Contexto, 2013. p. 39-59.

Prefeitura cria projeto para ampliação da área urbana de Uberlândia. G1 - Triângulo Mineiro, 22 de mai. 2013. Disponível em: <http://g1.globo.com/minas-gerais/triangulomineiro/noticia/2013/05/prefeitura-cria-projeto-para-ampliacao-da-area-urbana-deuberlandia.html >. Acesso em: 07 jul. 2020.

IBGE - INSTITUTO BRASILEIRO DE GEOGRAFIA E ESTATÍSTICA. Séries Históricas e Estatísticas - Taxa de Urbanização. [2020]. Disponível em: <https://seriesestatisticas.ibge.gov.br/series.aspx?vcodigo=POP122>. Acesso em: 10 abr. 2020.

MARICATO, Ermínia. Metrópole, Legislação e Desigualdade. Estudos Avançados/USP. [online]. São Paulo, v. 17, n. 48, p.151-166, 2003. Disponível em: <https://doi.org/10.1590/S0103-40142003000200013>. Acesso em: 31 jul. 2020.

MATOS, Ralfo; BAENINGER, Rosana. Migração e urbanização no Brasil: processos de concentração e desconcentração espacial e o debate recente. Cadernos do Leste, Belo Horizonte, v. 6, n. 6, p. 342-385, 2004.

Câmara aprova IPTU progressivo em Uberlândia. MGTV, 2. ed. [VÍDEO]. Uberlândia: TV Integração, 14 de dez. 2017. (Telejornal) Disponível em: <http://g1.globo.com/minas-gerais/triangulo-mineiro/mgtv-2edicao/videos/v/camaraaprova-iptu-progressivo-em-uberlandia/6357871/>. Acesso em: 09 jul. 2020.

MOTTA, Guilherme Augusto Soares da. Pensar, construir e viver a cidade Uberlândia-MG: setor sul. 2015. 228 f. Dissertação (Mestrado em Arquitetura e Urbanismo) - Faculdade de Arquitetura e Urbanismo e Design, Universidade Federal de Uberlândia, Uberlândia, 2015. 
PEREIRA, Talita Rodrigues. O desenho das habitações populares e sua influência sobre a privacidade e conflitos de convivência dos moradores: casos dos Residenciais Tocantins 1 e 2. 2017. 199 f. Dissertação (Mestrado em Arquitetura e Urbanismo) - Faculdade de Arquitetura e Urbanismo e Design, Universidade Federal de Uberlândia, Uberlândia, 2017.

SANTOS, Milton. Manual de Geografia Urbana. São Paulo: Hucitec, 1981.

. A urbanização brasileira. São Paulo: Hucitec, 1993.

A Natureza do Espaço: técnica e tempo, razão e emoção. 4. ed. 2. reimpr. (Coleção Milton Santos; 1). São Paulo: Editora da Universidade de São Paulo, 2006.

SILVA, Kássia Nunes da. Expansão urbana do setor sul da cidade de UberlândiaMG: um estudo dos processos de exclusão e segregação socioespacial. 2012. $150 \mathrm{f}$. Dissertação (Mestrado em Geografia) - Instituto de Geografia, Universidade Federal de Uberlândia, Uberlândia, 2012.

SOUZA, Josy Dayanny Alves. Segregação, habitação social e práticas socioespaciais: o mergulho no cotidiano. 2017. 196 f. Dissertação (Mestrado em Geografia) - Faculdade de Ciência Integradas do Pontal, Universidade Federal de Uberlândia, Ituiutaba, 2017.

TORRES, Walace. Prefeitura irá ampliar área isenta de IPTU progressivo. Diário de Uberlândia, Uberlândia, 22 outubro 2017. Disponível em: <https://diariodeuberlandia.com.br/noticia/13941/prefeitura-ira-ampliar-area-isentade-iptu-progressivo>. Acesso em: 09 jul. 2020.

UBERLÂNDIA. Lei Complementar no 78, de 27 de abril de 1994. Dispõe sobre o Plano Diretor do Município de Uberlândia. Disponível em: <http://leismunicipa.is/adpto>. Acesso em: 11 jul. 2020.

. Lei Complementar no 224, de 23 de dezembro de 1999. Dispõe sobre o Parcelamento e Zoneamento do Uso e Ocupação do Solo do Município de Uberlândia. Disponível em: <http://leismunicipa.is/botfp>. Acesso em: 07 jul. 2020.

. Lei Complementar no 245, de 30 de novembro de 2000. Dispõe sobre o Parcelamento e Zoneamento do Uso e Ocupação do Solo no Município de Uberlândia e revoga a Lei Complementar no 224 de 23 de dezembro de 1999 e suas alterações posteriores. Disponível em: <http://leismunicipa.is/ptocf>. Acesso em: 12 jul. 2020.

. Lei no 9080, de 25 de outubro de 2005. Dispõe sobre o Plano Municipal de Habitação "Tchau Aluguel" e dá outras providências. Disponível em: <http://leismunicipa.is/itgbq>. Acesso em: 02 jul. 2020.

. Lei Complementar no 432, de 19 de outubro de 2006. Aprova o Plano Diretor do Município de Uberlândia, estabelece os princípios básicos e as diretrizes para a sua implementação, revoga a Lei Complementar no 078 de 27 de abril de 
1994 e dá outras providências. Disponível em: <http://leismunicipa.is/pcgot>. Acesso em: 09 ago. 2020.

. Lei oㅜ 10.575, de 20 de setembro de 2010. Estabelece o perímetro urbano da sede do município de Uberlândia e revoga as Leis no 4.790 de 4 de outubro de 1988, e 5.969, de 7 de março de 1994 . Disponível em: <http://leismunicipa.is/jtqfd>. Acesso em: 07 jul. 2020.

. Lei Complementar $\mathrm{n}^{0}$ 521, de 16 de fevereiro de 2011. Dispõe sobre o solo urbano não edificado, subutilizado ou não utilizado, em regulamentação ao Art. 47 da Lei Complementar $n^{\circ}$ 432, de 19 de outubro de 2006 que "aprova o Plano Diretor do Município de Uberlândia" e dá outras providências. Disponível em: <http://leismunicipa.is/otgpf>. Acesso em: 07 jul. 2020.

. Lei Complementar no 523, de 07 de abril de 2011. [2011a]. Dispõe sobre o Parcelamento do Solo no Município de Uberlândia e seus distritos e dá outras providências. Disponível em: <http://leismunicipa.is/ogtfp>. Acesso em: 07 jul. 2020.

. Lei Complementar no 525, de 14 de abril de 2011. [2011b]. Dispõe sobre o Zoneamento do Uso e Ocupação do Solo no Município de Uberlândia e revoga a Lei Complementar no 245, de 30 de novembro de 2000 e suas alterações posteriores. Disponível em: <http://leismunicipa.is/pgotf>. Acesso em: 07 jul. 2020

. Lei o 11.412, de 19 de junho de 2013. [2013]. Estabelece o perímetro urbano da sede do município de Uberlândia e revoga a Lei no 10.575, de 20 de setembro de 2010. Disponível em: <http://leismunicipa.is/tqjhg>. Acesso em: 07 jul. 2020.

Lei Complementar o 567, de 1 de julho de 2013. [2013a]. Altera a Lei Complementar $n^{\circ} 525$, de 14 de abril de 2011, e suas alterações, que "dispõe sobre o Zoneamento do Uso e Ocupação do Solo do Município de Uberlândia e revoga a Lei Complementar no 245, de 30 de novembro de 2000 e suas alterações posteriores". Disponível em: <http://leismunicipa.is/gpoat>. Acesso em: 07 jul. 2020

. Lei Complementar no 640, de 5 de janeiro de 2018. [2018]. Altera a Lei Complementar $\mathrm{n}^{\circ} 521$ de 16 de fevereiro de 2011, que "Dispõe sobre o solo urbano não edificado, subutilizado ou não utilizado, em regulamentação ao Art. 47 da Lei Complementar no 432, de 19 de outubro de 2006 que aprova o Plano Diretor do Município de Uberlândia" e dá outras providências. Disponível em: <https://leismunicipais.com.br/a/mg/u/uberlandia/lei-complementar/2018/64/640/leicomplementar-n-640-2018-altera-a-lei-complementar-n-521-de-16-de-fevereiro-de2011-que-dispoe-sobre-solo-urbano-nao-edificado-subutilizado-ou-nao-utilizado-emregulamentacao-ao-art-47-da-lei-complementar-n-432-de-19-de-outubro-de-2006que-aprova-o-plano-diretor-do-municipio-de-uberlandia-e-da-outras-providencias $>$. Acesso em: 07 jul. 2020.

. Secretaria Municipal de Planejamento Urbano. Banco de Dados Integrados de Uberlândia (2019). Uberlândia: SEPLAN, v. 3, 2019. 
Lei Complementar o 673, de 6 de maio de 2019 [2019 a]. Altera a Lei Complementar no 525, de 14 de abril de 2011 que "Dispõe sobre o Zoneamento do Uso e Ocupação do Solo no Município de Uberlândia e revoga a Lei Complementar no 245, de 30 de novembro de 2000 e suas alterações posteriores e dá outras providências". Disponível em: <http://leismunicipa.is/qkxpo>. Acesso em: 12 jul.2020.

. Lei Complementar o 694, de 07 de outubro de 2019 [2019 b]. Altera a Lei Complementar no 525, de 14 de abril de 2011 e suas alterações, que dispõe sobre o Zoneamento do Uso e Ocupação do Solo do Município de Uberlândia e revoga a Lei Complementar no 245, de 30 de novembro de 2000 e suas alterações posteriores. Disponível em: <http://leismunicipa.is/xjkbu>. Acesso em: 07 jul. 2020.

. Lei Complementar no 679, de 3 de junho de 2019 [2019 c]. Institui e delimita as Zonas de Urbanização Específica que menciona, "dispõe sobre o Zoneamento do Uso e Ocupação do Solo do Município de Uberlândia e revoga a Lei Complementar no 245, de 30 de novembro de 2000 e suas alterações posteriores", e dá outras providências. Disponível em: <http://leismunicipa.is/lqdxr>. Acesso em: 07 jul. 2020

Secretaria Municipal de Desenvolvimento Social, Trabalho e Habitação. Programas Habitacionais - Tchau Aluguel. 2020. Disponível em: <https://www.uberlandia.mg.gov.br/prefeitura/secretarias/desenvolvimento-socialhabitacao-e-trabalho/programas-habitacionais/>. Acesso em: 08 jul. 2020.

Portaria no 49.512, de 9 de junho de 2020. [2020a]. Dispõe sobre os procedimentos administrativos a serem implementados para fins de cumprimento da Lei Complementar $n^{\circ} 521$, de 16 de fevereiro de 2011 e suas alterações. Diário Oficial do Município, Uberlândia, ano XXXII, noำ5886, 9 de junho de 2020.

VILLAÇA, Flávio. São Paulo: segregação urbana e desigualdade. Estudos Avançados, São Paulo, v. 25, n. 71, p.37-58, abril. 2011. 